\title{
Pengolahan Lidah Buaya (Aloe Vera) Menjadi Granul Effervescent sebagai Minuman Kesehatan dan Analisis Peningkatan Nilai Ekonomisnya
}

\author{
Muflihah Ramadhia* \\ Politeknik Negeri Pontianak, Indonesia \\ Ichsan \\ Politeknik Negeri Pontianak, Indonesia
}

\begin{abstract}
One of the leading sectors of commodities mainstay of West Kalimantan which have a comparative advantage, especially in the city and district of North Pontianak is aloe vera. Aloe vera usually processed and sale only in the form of raw material and provide little added economic value to society. The purpose of this study is knowing and producing effervescent granules with the best formulations as a health drink; and knowing and determining the economic value and feasibility level production of effervescent granules as a busniess unit. The result of this study indicate that, based on the soluble time test aloe vera effervescent granules are not eligible. Effervescent granules solubility test is qualified. Water content test of aloe vera effervescent granules is qualified. Flow time test of aloe vera effervescent granules is qualified. Meanwhile, based on the analysis of the calcualtion of the increase in economic value by using the calculation of Net Present Value (NPV), Net Benefit Cost Ratio (Net B/C), Internal Rate of Return (IRR), Payback Period (PP) and the Discounted Payback (DPB) expresses feasible to increase the economic value of public income.
\end{abstract}

Keywords: aloe vera, effervescent granules, increase economic value

\section{PENDAHULUAN}

Lidah buaya (aloe vera) merupakan komoditas sektor unggulan andalan Kalimantan Barat yang memiliki keunggulan komparatif, terutama di Kota Pontianak Utara dan Kabupaten Pontianak. Lidah buaya dapat tumbuh dengan baik di lahan gambut. Potensi potensial yang dapat dikembangkan untuk tanaman lidah buaya di kota

\footnotetext{
*Email: ramadhia99@gmail.com

Received: 08-06-2018, Accepted : 08-06-2018, Published : 18-08-2018

p-ISSN : 2087 - 9954, e-ISSN : 2550 - 0066. DOI: http://dx.doi.org/10.26418/jebik.v7i2.25991
} 
pontianak sekitar 1.100 ha dari 450.000 ha (Musyafak, 2003). Hasil produksi lidah buaya saat ini hanya sebagian kecil yang dimanfaatkan atau olahan terbatas di Kalimantan Barat khusunya Kota Pontianak selebihnya hasil produksi lidah dikirim atau dijual pada perusahaan agro industri di luar Kalimantan Barat, sehingga akibat hasil olahan terbatas dan penjualan keluar hanya dalam bentuk bahan baku hanya akan memberikan sedikit nilai tambah atau nilai ekonomis bagi masyarakat.

Untuk industri-industri pengolahan tanaman lidah buaya sudah banyak berkembang di luar Kalimantan Barat yang mengolah tanaman lidah buaya menjadi makanan, minuman kesehatan, masker, hand body, shampoo, penguat rambut, sunsilk, vaseline, shampoo biokos, hair tonic, dan masih banyak yang lainnya. Tanaman lidah buaya ini memiliki banyak manfaat antara lain adalah anti inflamasi, anti jamur, anti bakteri dan membantu proses regenerasi sel (Wahyono \& Kusnandar, 2002). Lidah buaya merupakan tanaman fungsional karena semua bagian dari tanaman dapat dimanfaatkan (Furwanti, 2002). Jurnal Alternative Medicine pada bulan Maret 1999 mempublikasikan "13 Ways Aloe Vera Can Help you" yang menyebutkan efektivitas lidah buaya dalam mengatasi berbagai masalah kesehatan. Beberapa masalah yang disebut dalam jurnal tersebut adalah gangguan pencernaan, mengatur keasaman lambung, meningkatkan kinerja lambung, menekan populasi mikro organisme tertentu, serta dapat berfungsi sebagai laksatif dan mengobati luka di dinding usus (Furwanti, 2002).

Salah satu yang dapat dilakukan pada tanaman Lidah Buaya (aloe vera) adalah melakukan pemanfaatan mengenai tanaman lidah buaya yang diolah menjadi minuman penyegar yang memberikan efek kesehatan. Minuman kesahatan dari bahan dasar lidah buaya ini diproduksi dalam bentuk granul effervescent. Minuman berbentuk bubuk effervescent yang bersifat fungsional banyak digemari seperti menyembuhkan panas dalam, sariawan, serta mengembalikan stamina setelah lelah berolah-raga dan bekerja (Pulungan, 2004).

Menurut Majalah Farmasi Indonesia granul effervescent merupakan bentuk sediaan yang disenangi oleh masyarakat saat ini karena mempunyai warna, bau dan rasa yang menarik. Keuntungan sediaan effervescent adalah penyiapan larutan dalam waktu seketika yang mengandung dosis yang tepat, penggunaannya lebih mudah dapat diberikan kepada pasien yang kesulitan menelan tablet atau kapsul dan larutan dengan karbonat yang dihasilkan dapat memberikan efek segar. Untuk produk lidah buaya sebagai minuman fungsional sudah banyak dikembangkan, salah satunya dalam bentuk gel namun dalam bentuk granul effervescent masih belum banyak dikembangkan bahkan masih tergolong baru. Hal ini dikarenakan butuhnya sentuhan pengetahuan dan teknologi dalam produksinya apa lagi harus memproduksinya dalam skala usaha bisnis salah satu penelitian terkait granul effervescent lidah buaya dilakukan oleh (Wijayanti, Saptarini, \& Herawati, 2014). 
Granul effervescent, dimana bentuk sediaan ini mempunyai beberapa keuntungan, diantaranya adalah mudah untuk dikonsumsi dan biasa dikembangkan variasi rasa, sehingga diharapkan masyarakat dapat tertarik untuk mengkonsumsi sediaan lidah buaya dalam bentuk granul effervescent, dan apabila ini dikembangkan menjadi unit usaha diharapkan dapat meningkatkan nilai ekonomis lidah buaya dan memberikan manfaat finansial bagi masyarakat. Berdasarkan penjelasan tersebut, maka memungkinkan dilakukannya sebuah penelitian mengenai "Pengolahan Lidah Buaya (Aloe Vera) Menjadi Granul Effervescent sebagai Minuman Kesehatan dan Analisis Peningkatan Nilai Ekonomisnya".

\section{KAJIAN LITERATUR}

\subsection{Granul Effervescent}

Granul effervescent merupakan granul atau serbuk kasar sekali mengandung unsur obat dalam campuran kering, biasanya terdiri dari natrium bikarbonat, asam sitrat dan asam tartrat, bila ditambahkan dengan air asam dan biasanya bereaksi membebaskan karbondioksida sehingga menghasilkan buih. Larutan dengan karbonat yang dihasilkan menutupi rasa garam atau rasa lain yang tidak diinginkan dari zat obat atau granul effervescent adalah granul berbuih dibuat dengan cara kompresi granul yang mengandung garam effervescent atau bahan-bahan lain yang mampu melepaskan gas ketika bercampur dengan air (Ansel, 1989).

\subsection{Metode Pembuatan Granul Effervescent}

Effervescent dapat diolah dengan memakai dua metode umum yaitu metode basah dan metode kering. Langkah awal menentukan formula yang tepat untuk sediaan yang akan menghasilkan pembuihan yang efektif dan penggunaan yang efisien dari asam dan basa yang tersedia, granul yang stabil dan produk yang nyaman rasanya serta manjur (Ansel, 1989). Effervescent biasanya diolah dari suatu kombinasi asam sitrat dan asam tartrat daripada hanya satu macam asam saja, karena penggunaan asam tunggal akan menimbulkan kesukaran. Jika asam tartrat sebagai asam tunggal, granul yang akan dihasilkan akan mudah kehilangan kekuatannya dan akan menggumpal (Ansel, 1989). Granul effervescent memerlukan kondisi kerja dan metode khusus dalam pembuatannya karena dalam granul ini terdapat dua bahan yang tidak dapat tersatukan yaitu garam natrium bikarbonat dan asam organik sebagai penghasil karbondioksida. Reaksi kedua bahan ini akan dipercepat dengan adanya air, maka dari itu granul effervescent selama perjalanannya mulai akhir produksi sampai ke tangan pasien tidak boleh sedikitpun kontak dengan air. Selain itu suhu tinggi juga dapat mempercepat perusakan bahan granul, sehingga juga harus dijaga pada suhu yang relatif rendah.

Beberapa cara pembuatan granul effervescent antara lain yaitu metode granulasi Basah. Teknik ini membutuhkan larutan suspensi atau yang mengandung pengikat yang biasanya ditambahkan campuran serbuk, namun demikian bahan pengikat yang dapat 
ditambahkan secara tersendiri (Lachman, L., Lieberman, H.A., Kaning, 1994). Merupakan metode yang tidak memerlukan sumber unsur penentu pada air kristal asam sitrat, akan tetapi boleh juga ditambahkan kedalam pelarut seperti alkohol yang digunakan sebagai unsur pelembap untuk membuat adonan bahan yang lunak dan larutan untuk pembuatan granul. Begitu cairan cukup ditambahkan (sebagian) untuk mengolah adonan pada kepadatannya yang tepat, baru granul diolah dan dikeringkan (Ansel, 1989).

Selanjutnya dengan metode granulasi kering yang merupakan alternatif lain untuk granulasi dengan menghindarkan reaksi effervescent adalah granulasi kering (slugging) dengan mesin kompresi. Granul dibentuk oleh pelembapan atau penambahan bahan pengikat kedalam campuran serbuk obat tetapi dengan cara memadatkan massa yang jumlahnya besar dari campuran serbuk dan setelah itu memecahkannya dan menjadikan pecahan-pecahan kedalam granul yang lebih kecil. Bahan aktif maupun pengisi harus memiliki sifat kohesif supaya massa yang jumlahnya besar dapat dibentuk.

Menurut Ansel (1989), selain memperbaiki sifat aliran, bentuk granul biasanya lebih stabil secara fisika dan kimia dari pada serbuknya. Menurut Voigt (1995) syaratsyarat granul yang baik adalah sebagai berikut: mempunyai bentuk dan warna yang sedapat mungkin homogen, memiliki distribusi butiran yang sempit dan tidak lebih dari 10\% mengandung komponen berbentuk serbuk, memiliki daya alir yang baik, mudah hancur dalam air, memiliki kekompakan mekanis yang memuaskan.

\subsection{Hasil Granul}

Terdapat variabel-variabel formulasi dan proses yang harus diperhatikan yang dapat mempengaruhi langkah-langkah pada pembuatan granul, semua variabel tersebut dapat mempengaruhi karakter dari granul yang dihasilkan (Parikh, 1997) Beberapa sifat yang mempengaruhi sifat dari granul diantaranya: Pertama, bentuk partikel merupakan parameter yang mempunyai efek yang signifikan pada sifat bulk dari serbuk, partikel yang berbentuk bola mengalir lebih baik, kemasan lebih baik dan mempunyai rasio permukaan atau volume yang lebih rendah. Melalui uraian linier dimensional (lebar, panjang, tinggi) beberapa data mengenai bentuk dapat diperoleh, lebar biasanya menegaskan jarak antara dua garis paralel yang memisahkan partikel, sedangkan panjang adalah jarak maksimum antara dua garis paralel yang menyatukan partikel dan merupakan garis tegak lurus dengan lebar. Tinggi secara teknis merupakan sandaran partikel dalam orientasinya ke yang untuk partikel yang sangat kecil, karena untuk melihatnya harus menggunakan mikroskop.

Kedua, ukuran partikel dimana partikel dari serbuk obat mungkin berbentuk sangat kasar dengan ukuran \pm 10.000 mikron atau 10 milimikron atau mungkin juga sangat halus mencapai ukuran kloidal, 1 mikron atau lebih kecil. Pengukuran besar partikel dan besar distibusi dapat menggunakan standar atau kontrol sebagai pembanding dan untuk memperoleh informasi mengenai besar sistem pengukuran dapat digunakan 
standar sebagai kalibrasi. Standar yang digunakan harus berupa partikel yang sangat ideal dengan derajat bentuk yang tepatan memiliki distribusi besaran yang terbatas. Penyesuaian dan pengembangan yang terus-menerus dari metode pengukuran besaran dapat diselesaikan untuk memastikan reabilitas, reproduksibilitas dan sensitivitas dari metode pengukuran. Beberapa faktor yang dapat menentukan besar dan bentuk partikel adalah mikroskopik, sedimentasi, ayakan, gaya elektrik, penyebaran cahaya, spektoskopi korelasi foton.

Ketiga, tegangan permukaan partikel yang mana pengukuran umumnya dilakukan melalui permeabilitas gas maupun adsorpsi. Teknik permeabilitas gas tergantung dari pengukuran ketahanan aliran gas melalui permukaan yang membungkus partikel. Pengukuran yang lebih baik atau akurat dapat dilakukan dengan mengukur aliran gas dengan tekanan yang dikurangi, tetapi ketelitian masih belum dapat diperoleh melalui adsorpsi gas jika total area yang akan ditentukan menutupi pori-pori yang halus. Adsorpsi gas dilakukan dengan cara menempatkan suatu sampel serbuk dalam cawan dan mengeluarkan udara yang ada didalamnya.

Keempat, solubilitas yang bahannya biasa ditentukan melalui metode keseimbangan kelarutan, dengan menggunakan larutan yang jenuh akan bahan. Larutan jenuh tersebut diperoleh dengan menggerakkan kelebihan bahan dalam pelarut dalam waktu yang diperpanjang, dan pada suhu yang tetap, sampai diperoleh kesetimbangan tersebut. Faktor-faktor yang dapat mempengaruhi solubilitas suatu bahan adalah pelarut itu sendiri, temperatur, sifat kristal dari bahan, ukuran partikel, $\mathrm{pH}$ dan penambahan bahan aditif.

Kelima, yaitu sifat kristal dan polimorfisme. Suatu bahan mungkin terbentuk sebagai zat yang tidak berbentuk tanpa banyak keterbatasan struktur (amorf) atau sebagai partikel kristal dengan keterbatasan struktur dan bentuk. Beberapa bahan mungkin lebih banyak bertahan pada suatu bentuk kristal tergantung dari kondisi lingkungan seperti temperatur dan tipe pelarut. Pada temperatur atau tekanan yang spesifik, lebih dari satu polimorfisme dapat terbentuk, namun hanya satu yang stabil secara termodinamika. Akhirnya baik bentuk stabil maupun metastabil akan menjadi lebih stabil bersamaan dengan berjalannya waktu. Perbedaan bentuk kristal dari suatu bahan secara umum berbeda pula dalam karakteristik fisika seperti kelarutan, titik lebur, sifat optik dan elektrik, kerapatan, kekerasan dan stabilitasnya. Polimorfisme yang metastabil mempunyai nilai solubilitas atau kelarutan dan disolusi lebih tinggi dibandingkan dalam bentuk polimorfisme stabil yang lebih resisten terhadap degradasi secara kimia.

Selanjutnya yang terakhir adalah bahan baku. Selain bahan aktifnya yaitu ekstrak kental lidah buaya yang diperoleh melalui proses maserasi, kemudian dikeringkan dengan molen dry/cabinet drying sehingga diperoleh serbuk ekstrak lidah buaya, bahan baku lainnya untuk produk effervescent adalah senyawa asam dan natrium bikarbonat. Asam sitrat adalah salah satu asam tribasik hidroksil dikenal sebagai rasa alamiah yang terdapat dalam buah-buahan bersama dengan vitamin $\mathrm{C}$ yang berbentuk granula atau 
bubuk putih, tidak berbau dan berfungsi sebagai pemberi asam, serta cepat larut dalam air (kelarutan dalam air dingin lebih cepat). Kelemahan asam sitrat adalah sifatnya yang sangat higroskopis sehingga memerlukan perhatian yang cukup dalam penyimpanan (Hindun, P. M., 2004).

Asam tartrat merupakan asam yang biasa digunakan sebagai sumber asam effervescent. Asam tartrat kelarutannya lebih baik dan lebih higroskopis dibandingkan asam sitrat (Lachman, L., Lieberman, H.A., Kaning, 1994). Natrium Bikarbonat $\left(\mathrm{NaHCO}_{3}\right)$ merupakan serbuk kristal berwarna putih yang memiliki rasa asin dan mampu menghasilkan karbondioksida. Senyawa karbonat yang banyak digunakan dalam formulasi effervescent adalah garam karbonat kering. Karena kemampuannya menghasilkan karbondioksida. Sodium bikarbonat sering disebut juga dengan soda kue atau baking powder (Monrle, 1989).

\subsection{Bahan Tambahan dalam Granul Effervescent}

Bahan tambahan dapat berfungsi sebagai zat pemanis, zat pengikat, dan zat pengisi. Pemanis digunakan untuk memberikan rasa yang enak pada mulut dan menutupi atau memperbaiki rasa obat yang kurang menyenangkan. Macam-macam pemanis yang sering digunakan adalah sukrosa, sakarin, aspartame, natrium siklamat, sorbitol dan manitol (Lieberman, 1989).

Bahan pengikat adalah bahan yang digunakan untuk melekatkan bahan-bahan lain secara bersamaan. Gom, gelatin dan amilum merupakan pengikat dari bahan alam tetapi untuk pembuatan granul effervescent dengan metode granulasi, bahan-bahan tersebut biasanya tidak digunakan karena faktor kelarutan dan akan meningkatkan residu. Bahan pengikat kering seperti laktosa, dekstrosa dan manitol dapat digunakan, tetapi kurang efektif karena penggunaannya harus dalam konsentrasi yang tinggi. Pengikat yang paling efektif dan banyak digunakan adalah Poli Vinyl Pirolidon (PVP), merupakan pengikat dalam bentuk kering dan diaktifasi dengan alkohol atau air atau dalam bentuk terlarut dalam air atau hidroalkohol (Lieberman, 1989).

Bahan pengisi ditambahkan untuk meningkatkan volume dan massa produk. Bahan pengisi untuk sediaan effervescent hanya dibutuhkan dalam jumlah kecil karena sudah mengandung asam dan karbonat dalam jumlah besar. Bahan pengisi yang biasa digunakan antara lain: laktosa, glukosa, maltodekstrin. Bahan pengisi banyak digunakan pada proses pengolahan pangan untuk melapisi komponen penambahan cita rasa, mempercepat proses pengeringan dan mencegah kerusakan akibat panas. Salah satu pengisi yang sering digunakan adalah maltodekstrin (Lieberman, 1989).

\subsection{Preformulasi}

Ekstrak lidah buaya adalah ekstrak kental yang diperoleh melalui proses maserasi yang kemudian di molen dry sehingga diperoleh serbuk ekstrak lidah buaya. Natrium 
bikarbonat mengandung tidak kurang dari 99,0\% dan tidak lebih dari 100,5\% $\mathrm{NaHCO}_{3}$ dihitung terhadap zat yang telah dikeringkan. Pemberian serbuk hablur putih, stabil di udara kering tetapi dalam udara lembab secara perlahan-lahan terurai. Larutan segar dalam air dingin, tanpa dikocok, bersifat basa terhadap lakmus. Kebasaan bertambah jika larutan dibiarkan digoyang kuat atau dipanaskan (Depkes, 1995)

Asam tartrat yang dikeringkan diatas fosfor pentoksida pekat selama tiga jam, mengandung tidak kurang dari 99,7\% dan tidak lebih dari 100,5\% $\mathrm{C}_{3} \mathrm{H}_{6} \mathrm{O}_{6}$. Pemerian hablur, tidak berwarna atau bening atau serbuk hablur halus sampai granul, warna putih, tidak berbau, rasa asam dan stabil diudara. Sangat mudah larut dalam air, dan mudah larut dalam etanol (Depkes, 1995). Asam sitrat berbentuk anhidrat atau mengandung satu molekul air hidrat. Mengandung tidak kurang dari 99,5\% dan tidak lebih dari 100,5\% $\mathrm{C}_{6} \mathrm{H}_{8} \mathrm{O}_{7}$ dihitung terhadap zat anhidrat. Pemberian hablur bening atau tidak berwarna atau serbuk hablur granul sampai halus, putih, tidak berbau atau praktis tidak berbau, rasa sangat asam, bentuk hidrat mekar dalam udara kering. Sangat mudah larut dalam air dan mudah larut dalam etanol, serta sukar larut dalam eter (Depkes, 1995).

Manitol mengandung tidak kurang dari 96,0\% dan tidak lebih dari 101,5\% $\mathrm{C}_{6} \mathrm{H}_{14} \mathrm{O}_{6}$ dihitung terhadap zat yang telah dikeringkan. Pemerian serbuk hablur atau granul mengalir bebas; putih; tidak berbau ;rasa manis. Mudah larut dalam air; larut dalam larutan basa; sukar larut dalam piridina; sangat sukar larut dalam etanol; praktis tidak larut dalam eter (Depkes, 1995).

Polivinilpirolidon pemberian serbuk putih atau putih kekuningan, berbau lemah atau tidak berbau, higroskopik. Mudah larut dalam etanol dan dalam air (Depkes, 1995). Natrium benzoat mengandung tidak kurang dari $99,0 \% \mathrm{C}_{7} \mathrm{H}_{5} \mathrm{NaO}_{2}$ dihitung terhadap zat anhidrat. Pemberian granul atau serbuk hablur, putih; tidak berbau atau praktis tidak berbau, stabil di udara. Mudah larut dalam air,agak sukar larut dalam etanol dan lebih mudah larut dalam etanol 90\% (Depkes, 1995).

\subsection{Nilai Ekonomis dan Penilaian Kelayakan Usaha}

Nilai ekonomis dilihat dari aspek ekonomi adalah untuk melihat seberapa besar pengaruh yang ditimbulkan jika usaha ini dijalankan. Pengaruh terutama terhadap ekonomi secara luas serta dampak sosialnya terhadap masyarakat secara keseluruhannya. Dampak ekonomi tertentu, peningkatan pendapatan masyarakat baik yang bekerja dipabrik atau masyarakat di luar lokasi pabrik.

Tingkat kelayakan suatu usaha dapat dinilai dengan menggunakan kriteriakriteria investasi : (a) Net Present Value (NPV), yaitu metode yang menghitung selisih antara nilai sekarang investasi dengan nilai sekarang penerimaan-penerimaan kas bersih di masa yang akan datang. Jika NPV positif maka proyek investasi layak. Jika NPV negatif maka proyek investasi tidak layak (Riyanto, 2001) ; (b) Internal Rate of return (IRR) merupakan metode yang menghitung tingkat bunga yang menyamakan nilai 
sekarang investasi dengan nilai sekarang penerimaan-penerimaan kas bersih dimasa yang akan datang. Kriteria Seleksi diantaranya: jika IRR $>$ dari tingkat bungan yang disyaratkan, maka proyek investasi layak dan jika IRR $<$ dari tingkat bunga yang disyaratkan, maka proyek investasi kurang layak (Sutrisno, 2009); (c) Profitability Index (PI), Profitability Index yaitu untuk menghitung perbandingan antara present value dan penerimaan dengan present value dari investasi, dan (d) Payback Period (PP), adalah periode yang diperlukan untuk kembali dana yang telah dikeluarkan atau diinvestasikan. Kriteria seleksi, diantaranya : Jika payback period lebih kecil dibanding dengan target kembalinya investasi, maka proyek investasi layak, dan jika payback period lebih besar dibanding dengan target kembalinya investasi, maka proyek tidak layak (Sutrisno, 2009).

Beberapa industri kecil yang telah melakukan pengolahan makanan dan minuman funsional berbahan baku lidah buaya, nenas, pisang, buah naga dengan skala usaha mikro, kecil dan menengah (Disperindagko \& UMKM, 2016).

\section{METODA PENELITIAN}

Metode penelitian meliputi pembuatan granul effervescent, dan analisis ekonomis usaha.

\subsection{Bahan dan Alat}

Bahan-bahan yang digunakan adalah lidah buaya kering (aloe vera $L$ ), alkohol 96\%, aquadest, isopropl alkohol, PVP, natrium bikarbonat, asam sitrat, asam tartrat, natrium benzoat, manitol. Peralatan yang digunakan dalam percobaan ini yaitu, beaker glass, erlenmeyer, labu ukur, corong,alat pengaduk, oven, grinder, cabinet drying, pengayakan (mesh 14, mesh 40 dan mesh 60) neraca ohaus gram, saringan, alat-alat gelas, rotary evaporator, stopwatch, $\mathrm{pH}$ meter, spektrofotometer, granul flow meter, penangas air, moisture balance dan sarung tangan.

\subsection{Populasi dan Sampel}

Populasi pada penelitian adalah tanaman lidah buaya (aloe vera $L$ ) yang ada di Kota Pontianak. Sampel menggunakan teknik random sampling yang digunakan pada penelitian ini adalah lidah buaya (aloe vera $L$ ) yang diambil langsung dari Perkebunan aloe vera di 28 Oktober Kota Pontianak.

\subsection{Formulasi Granul Effervescent}

Ada 3 formula yang akan dibuat untuk masing-masing ekstrak granul. Rancangan formulasi yang selengkapnya ditampilkan pada Tabel 1 . 
Tabel 1. Rancangan Formula Granul Effervescent Ekstrak Lidah Buaya.

\begin{tabular}{lccc}
\hline \multicolumn{1}{c}{ Jenis Bahan } & \multicolumn{3}{c}{ Formula (\%) } \\
& F1 & F2 & F3 \\
\hline Serbuk kering ekstrak lidah buaya & 40 & 60 & 80 \\
PVP & 4,5 & 6 & 7,5 \\
Natrium & 45 & 45 & 45 \\
bikarbonat & & & \\
Asam sitrat & 19,5 & 19,5 & 19,5 \\
Asam tartat & 25,5 & 25,5 & 25,5 \\
Natrium benzoat & 3 & 3 & 3 \\
Manitol & $\mathrm{Ad} \mathrm{300}$ & $\mathrm{Ad} 300$ & $\mathrm{Ad} \mathrm{300}$ \\
\hline
\end{tabular}

\subsection{Pembuatan Granul Effervescent}

Granul Effervescent dibuat dengan menggunakan metode granulasi basah. Pisahkan antara komponen asam dan komponen basa. Komponen basa (zat aktif atau ekstak kering lidah buaya dan Natrium bikarbonat) dikeringkan dengan suhu $35-40^{\circ} \mathrm{C}$ selama 24 jam. Komponen asam (asam sitrat dan asam tartrat) dikeringkan dengan suhu $35-40^{\circ} \mathrm{C}$ selama 24 jam. Pada komponen basa kemudian dtambahkan Natrium benzoate dan sebagian PVP sebagai pengikat daan ditambahkan larutan isopropyl alcohol sampai kalis, kemudian digranulasi dengan ayakan Mesh 40.

Pada komponen asam ditambahkan manitol dan sebagian PVP serta ekstrak lidah buaya kemudian ditambahkan isopropil alkohol sampai kalis, lalu diayak dengan menggunakan ayakan Mesh 40. Kemudian komponen asam dan komponen basa dikeringkan dalam open bersuhu $60^{\circ} \mathrm{C}$ sampai kadar air 4-5\%. Lalu diayak dengan ayakan Mesh 14. Lalu campur komponen asam dan basa dalam ruangan bersuhu 25$30^{\circ} \mathrm{C}$. Campur granul asam dan granul basa hingga homogen.

\subsection{Evaluasi Granul Effervescent Ekstrak Lidah Buaya}

Setelah diperoleh granul dari setiap formula, kemudian dilakukan uji terhadap massa tersebut. Pengujian meliputi uji aliran granul, yaitu uji aliran granul, uji kadar air uji waktu larut, dan uji kelarutan

\subsubsection{Uji Aliran Granul Effervescent}

Menimbang 100 g kemudian memasukkan ke dalam corong dengan lubang bawah ditutup. Lalu mengukur waktu alir dimulai pada saat lubang corong dibuka sampai granul seluruhnya keluar dari corong. Aliran granul baik jika waktu yang diperlukan untuk mengalirkan $100 \mathrm{~g}$ granul kurang dari $<10$ detik atau dengan uji aliran granul dilakukan untuk mengetahui homogenitas serbuk dan keseragaman pengisian granul. Pengujian dilakukan dengan cara menimbang $50 \mathrm{~g}$ massa granul lalu dimasukan 
ke dalam alat flowmeter. Catat waktu seluruh massa melewati corong. Pengujian dilakukan tiga kali. Syarat waktu alir yang baik $<10 \mathrm{~g} /$ detik (Voigt, 1995). Tipe aliran yang baik berdasarkan daya alir dapat dilihat pada Tabel 2 .

Tabel 2. Tipe Aliran Berdasarkan Daya Alir (Aulton, 1988)

\begin{tabular}{ll}
\hline Harga daya alir $(\mathrm{g} /$ detik $)$ & Keterangan \\
\hline$>10$ & Bebas mengalir \\
$4-10$ & Mudah mengalir \\
$1,4-4$ & Kohesif \\
$<1,4$ & Sangat kohesif \\
\hline
\end{tabular}

Daya alir dapat dihitung menggunakan rumus :

$\mathrm{a}=\frac{M}{T}$

dimana :

a $\quad=$ Laju aliran (gram/detik)

$\mathrm{T} \quad=$ Waktu (detik)

$\mathrm{M} \quad=$ Massa granul (gram)

\subsubsection{Penentuan Kadar Air Granul}

Uji ini dilakukan untuk mengetahui kadar air yang terdapat dalam sediaan granul effervescent. Kadar air penting dalam sediaan ini karena jumlah air dapat mempengaruhi reaksi kimia dini dari komponen asam dan basa yang terdapat dalam komposisi effervescent. Penetapan kadar air granul dilakukan dengan menggunakan alat Moisture Balance AND MX-50. Cara kerjanya : dinyalakan alat, pinggan disimpan di bagian tengah dan penahan punch di atasnya. Pengaturan secara keseluruhan baik program, akurasi maupun temperatur sesuai dengan jumlah sampel yang diujikan. Punch disimpan di atas penyangga kemudian ditara. Ditimbang sampel sebanyak $5 \mathrm{~g}$ (akurasi sedang). Sampel disimpan di atas punch kemudian sampel diratakan sampai menutupi permukaan punch, lalu ditutup. Setelah proses selesai, maka persen kadar dari sampel akan tertera secara otomatis. Persyaratan kadar air granul yang baik adalah 3-5\% (Voight, 1995). Granul effervescent ekstrak temu kunci sebanyak $10 \mathrm{~g}$, dimasukkan dalam oven pada suhu $105^{\circ} \mathrm{C}$, kemudian masukkan eksikator selama 1 jam kemudian dihitung kadar airnya dengan rumus :

Bobot sebelum - bobot sesudah X $100 \%$ 
Bobot sebelum

\subsubsection{Uji Waktu Larut}

Dilarutkan 1 bungkus granul effervescent pada satu gelas yang berisi air $(220 \mathrm{ml})$ lalu diamati dan dihitung lama seidaan yang larut dalam air sampai partikel - partikel tidak terlihat atau larut sempurna. Granul effervescent yang baik larut dalam waktu $\leq 1$ menit. Lakukan sampai tiga kali.

\subsubsection{Uji Kelarutan}

Larutkan $3 \mathrm{~g}$ granul effervescent dengan $100 \mathrm{ml}$ air, saring dengan kertas saring yang sudah diketahui beratnya. Kemudian di oven $105 \mathrm{oC}$ selama 3 jam. Dinginkan dalam eksikator dan timbang sampai di dapatkan berat yang konstan.

\subsection{Analisis Kelayakan Finansial dan Analisis Sensitivitas}

Analisis kelayakan finansial dilakukan terhadap perlakuan proporsi formulasi Granul Effervescent Lidah Buaya terbaik dan yang terpilih berdasarkan metode pengambilan keputusan yang dipergunakan. Kriteria-kriteria kelayakan finansial yang akan diukur meliputi (Husnan \& Suwarsono, 1991): Net Present Value, Break Even Point (kg, Rp), Internal Rate of Return, Payback Period. Analisis Ekonomi diantaranya:

1. Biaya Produksi

Total biaya produksi $=$ total fixed cost + total variable cost

2. Biaya Perawatan Dan Perbaikan (BPP)

$$
\mathrm{BPP}=\frac{\mathrm{P} \times \% \mathrm{FPP} \times \mathrm{P} \times \mathrm{jam}}{1000}
$$

dimana:

$\mathrm{FPP}=$ faktor perawatan dan perbaikan

3. Penyusutan/Depresiasi

$$
\text { Depresiasi }=\frac{\mathrm{P}-\mathrm{NS}}{\mathrm{N}}
$$

dimana:

P : Harga peralatan awal

NS : Biaya penyusutan

$\mathrm{N} \quad$ : Jumlah Bulan 


\section{Pajak Usaha}

5. Harga Pokok Penjualan

$$
\mathrm{HPP}=\frac{\text { Biaya Produksi }}{\text { Kapasitas Produksi }}
$$

6. Perhitungan Penjualan

Penjualan $=$ Harga/unit $\mathrm{x}$ jumlah unit

7. Perhitungan Rugi Laba

Laba kotor $=$ Penjualan-Biaya Pokok Produksi

Laba bersih $=$ Laba Operasi - Pajak Usaha

8. BEP (Break Even Point)

$\mathrm{Q}_{\mathrm{BEP}}=\quad \mathrm{FC}$

$$
\text { Harga Jual - (VC/Kapasitas Produksi) }
$$

9. ROI (Return on Investment)

$$
\text { ROI sebelum pajak }=\frac{\text { Laba Kotor }}{\text { Total Biaya Produksi }}
$$

ROI sesudah pajak $=\quad$ Laba Bersih

Total Biaya Produksi

10. POT (Pay Out Time)

POT merupakan waktu yang dibutuhkan oleh perusahaan untuk mendapatkan pengembalian modal dan mendapatkan keuntungan bersih.

POT $=$ Biaya Produksi

Laba Kotor

11. B/C Ratio (Benefit Cost Ratio)

$\mathrm{B} / \mathrm{C}$ Ratio = Laba Kotor

Total Biaya Produksi

12. IRR (Internal Rate of Return)

$$
I R R=D F 1+\frac{N P V 1}{N P V 1-N P V 2}(D F 2-D F 1)
$$




\section{HASIL PENELITIAN DAN PEMBAHASAN}

\subsection{Uji Mutu Fisik Granul Effervescent Lidah Buaya}

Proses pembuatannya dimulai dari ekstraksi menggunakan metode maserasi. Lalu di granulasi sampai berbentuk granul, setelah itu baru proses pencampuran dengan bahan - bahan lainnya. Setelah sediaan jadi granul effervescent dilakukan uji mutu fisik. Pada uji waktu larut granul effervescent replikasi 1, 2, dan 3 dinyatakan tidak memenuhi syarat. Rata-rata waktu larutnya lebih dari satu menit, disebabkan pengaruh suhu ruangan selama proses pembuatan. Suhu ruangan yang diharapkan adalah suhu kamar $\left(37^{\circ} \mathrm{C}\right)$. Selain itu keseragaman ukuran partikel (granul) tidak seragam, granul ekstrak lidah buaya berbeda dengan bahan tambahannya (asam sitrat, asam tartrat dan natrium bikarbonat), hal ini mempengaruhi waktu larut sehingga granul effervescent ekstrak lidah buaya tersebut lambat waktu larutnya dan tidak memenuhi syarat. Syarat yang baik adalah waktu larutnya $<1$ menit (60 detik).

Pada uji waktu alir granul effervescent ekstrak temu kunci replikasi 1, 2 dan 3 memenuhi syarat. Rata - rata waktu alirnya kurang dari 10 detik. Sedangkan uji kadar air yang diperoleh pada replikasi 1, 2 dan 3 tidak memenuhi syarat. Syarat untuk kadar air granul effervescent yang baik yaitu antara 0,4-0,7 \%. Dan pengaruh suhu ruangan selama proses pembuatan. Suhu ruangan yang diharapkan adalah suhu kamar $\left(37^{\circ} \mathrm{C}\right)$. Pada uji kelarutan menghasilkan prosentase yang baik, dari replikasi 1,2 dan 3 rata- ratanya 96,60\% memenuhi syarat dan terbukti bahwa lidah buaya larut dalam air dan layak dibuat sediaan granul effervescent. Uji mutu fisik granul effervescent dari ekstrak lidah buaya meliputi uji waktu aliran granul. uji kadar air, uji waktu larut, dan uji kelarutan.

Tabel 3. Hasil uji waktu alir granul

\begin{tabular}{lcc}
\hline & Replikasi & Uji waktu alir (detik) \\
\hline & 1 & 9,15 \\
& 2 & 9,40 \\
& 3 & 8,60 \\
Rata - rata & & 9,05 \\
SD & & 0,40 \\
\hline
\end{tabular}

Pada uji waktu alir rata - ratanya 9,05 detik dengan standart deviasi 0,40.

Tabel 4. Hasil uji kadar air

\begin{tabular}{lcc}
\hline & Replikasi & Uji kadar air (\%) \\
\hline & 1 & 0,65 \\
& 2 & 0,69 \\
Rata - rata & 3 & 0,73 \\
SD & & 0,69 \\
\hline
\end{tabular}


Uji kadar air rata - ratanya 0,69 \% dengan standar deviasi 0,020 .

Tabel 5. Hasil uji waktu larut

\begin{tabular}{|c|c|}
\hline Replikasi & Uji Waktu larut (detik) \\
\hline 1 & 65 \\
\hline 2 & 74 \\
\hline 3 & 71 \\
\hline Rata - rata & 70 \\
\hline SD & 5,12 \\
\hline
\end{tabular}

Pada uji waktu larut dari ketiga replikasi rata-ratanya 70 detik dengan standar deviasi 5,12 .

Tabel 6. Hasil uji kelarutan

\begin{tabular}{lcc}
\hline & Replikasi & Uji kelarutan $(\%)$ \\
\hline & 1 & $96,62 \%$ \\
& 2 & $96,18 \%$ \\
& 3 & $97,02 \%$ \\
Rata - rata & & 96,60 \\
SD & & 0,420 \\
\hline
\end{tabular}

Sedangkan uji kelarutan dari ketiga replikasi rata - ratanya 96,60 \% standar deviasinya 0,420 .

4.2. Analisis Nilai Ekonomis Berdasarkan Analisis Finansial dari Tingkat Kelayakan Produksi Granul Effervescent sebagai Unit Bisnis.

Usaha pengolahan lidah buaya (aloe vera) menjadi granul effervescent sebagai minuman kesehatan adalah merupakan usaha yang berbasis sumber daya lokal, sehingga mampu menjadi sektor yang tangguh, karena tidak tergantung pada pasokan bahan baku dari luar, dan selama ini pasokan bahan baku cukup banyak. Dalam pelaksanaan usaha, meskipun tenaga kerja yang dibutuhkan relatif kecil, namun seluruh kebutuhan tenaga kerja tersebut dapat dipenuhi dari dalam daerah itu sendiri. Dengan demikian, usaha ini mempunyai potensi untuk meningkatkan kesejahteraan masyarakat setempat. Mengingat pelaksanaan usaha hanya memerlukan teknologi yang sederhana, maka tidak diperlukan persyaratan khusus bagi tenaga kerja.

Usaha ini juga mempunyai potensi untuk menyumbangkan pajak bagi pemerintah sebagai peningkatan pendapatan asli daerah (PAD). Berdasarkan uraian 
di atas, dampak yang dihasilkan dari usaha ini baik dari segi ekonomi maupun sosial adalah positif. Mengingat keterkaitan antara sub sistem dalam pengusahaan ini sangat erat maka perkembangan usaha ini akan mampu menggerakkan industri hulu dan industri hilir.

\subsubsection{Skala produksi}

Skala produksi optimum dipengaruhi oleh kapasitas mesin pengepres, mesin manual memiliki kapasitas produksi 360 bungkus/sachet dan untuk mesin pressing kemasan sachet semi otomatis memiliki kapasitas produksi 820 bungkus/sachet per hari. Jadi, total kapsitas produksi kedua mesin tersebut adalah 1.180 bungkus/sachet per hari dengan waktu produksi 8 jam per hari. Kapasitas optimum yang dapat dicapai kedua mesin adalah 1.918 bungkus/sachet per hari dengan waktu produksi 13 jam per hari.

\subsubsection{Kendala produksi}

Pembuatan granul effervescent lidah buaya tergantuug pada kapasitas produksi mesin, kabinet drying, pengepres dan alat sterilisasi hasil prosesing. Dengan demikian perlu sekali menggunakan mesin yang memiliki kapasitas produksi tinggi dan menjamin sterilisasi yang handal, selain itu juga ketersediaan pasokan pelepah lidah buaya segar dan bahan kimia sebagai baku utama industri tersebut.

\subsubsection{Kebutuhan dana dan sumbernya}

Dana yang dibutuhkan pada permulaan tahun adalah sebesar Rp.64.164.300 (enam puluh empat juta seratus enam puluh empat ribu tiga ratus rupiah). Untuk investasi aktiva tetap sebesar Rp.38.517.500 terdiri dari (biaya bangunan dan sewa, mesin serta peralatan pabrik) dan modal kerja selama satu bulan sebesar Rp.25.646.800,- (terdiri dari: bahan baku utama, bahan baku penunjang, biaya transport, biaya tenaga kerja lepas, biaya listrik dan air, biaya kemasan dan biaya lain-lain). Semua investasi mengunakan modal sendiri.

Secara garis besar sumber dana dapat dibagi menjadi dua yaitu: biaya dan manfaat. Biaya terbagi ke dalam dua komponen, yaitu biaya tetap dan biaya tidak tetap. Biaya tetap pada awal tahun (pada bulan ke-0) meliputi biaya konstruksi, bangunan pabrik, mesin-mesin dan peralatan penunjang operasional pabrik lainnya yang seluruhnya berjumlah Rp.38.517.500. Setiap dua tahun sekali dilakukan reinvestasi atas peralatan penunjang operasional pabrik sejumlah $\mathrm{Rp}$ 6.917.500. Biaya tetap pada saat industri mulai berjalan terdiri dari biaya gaji tenaga ahli dan manajer pabrik. Biaya tidak tetap terdiri dari biaya pengadaan pelepah lidah buaya segar, bahan kimia (alkohol 96\%, 
aquadest, isopropl alkohol, PVP, natrium bikarbonat, asam sitrat, asam tartrat, natrium benzoat, manitol), biaya bahan bakar, biaya kemasan, upah 3 orang tenaga kerja lepas pabrik, biaya listrik dan air, transport dan lain-lain yang keseluruhannya berjumlah Rp.25.646.800,-/bulan.

Manfaat usaha ini diperoleh dari nilai penjualan produksi. Penjualan produksi dilakukan tiap hari dengan kapasitas produksi 1.180 bungkus/sachet perhari dengan harga perbungkus/persachet sebesar Rp.1.050. Volume penjualan pada tahun pertama diperkirakan mencapai 90 persen dari total penjualan setelah dilakukan promosi selama dua bulan. Penjualan tahun berikutnya sampai tahun kesepuluh diasumsikan tetap hanya mencapai 90 persen dari total penjualan. Penjualan dilakukan melalui jaringan agensi. Asumsi volume penjualan di atas berdasarkan pertimbangan kerusakan atau kegagalan dalam proses produksi sebesar 10 persen.

4.2.4. Hasil Analisis Nilai Ekonomis Berdasarkan Analisis Finansia dari Tingkat Kelayakan Produksi Granul Effervescent sebagai Unit Bisnis.

Hasil analisis kelayakan investasi usaha ini meliputi kriteria NPV, Net B/C, IRR dan Payback Period (PP) atau Discounted Payback (DPB). Perhitungan kelayakan investasi usaha ini diperoleh dari data hasil pengurangan aliran kas manfaat dengan aliran kas biaya yang timbul akibat adanya kegiatan operasional proyek. Manfaat bersih sesudah pajak dan ditambah penyusutan yang diperoleh kemudian di diskontokan untuk mengetahui tingkat kelayakan investasi. Hasil perhitungan NPV, Net B/C, IRR dan PBP atau DPB industri kecil pengolahan lidah buaya (aloe vera) menjadi granul effervescent sebagai minuman kesehatan dapat dilihat pada Tabel 7 di bawah ini:

Tabel 7. Hasil Analisis NPV, Net BIC, IRR, PP dan DPB

\begin{tabular}{clcc}
\hline No & Alat Analisis & Hasil Analisis & Keterangan \\
\hline 1. & Net Present Value $(N P V)$ & 47.416 .941 & Layak \\
\hline 2. & Net Benefit Cost Ratio $($ Net B/C) & 1,74 & Layak \\
\hline 3. & Internal Rate of Return (IRR) & $35,35 \%$ & Layak \\
\hline 4. & Payback Period $(P P)$ & 3th $0 \mathrm{bl} 8 \mathrm{hr}$ & Layak \\
\hline 5. & Discounted Payback $(D P B)$ & 4th $5 \mathrm{bl} 26 \mathrm{hr}$ & Layak \\
\hline
\end{tabular}

Berdasarkan hasil analisis kelayakan investasi pada Tabel 7, usaha pengolahan lidah biaya (aloe vera) menjadi granul effervescent sebagai minuman kesehatan memiliki NPV sebesar 47,417 juta yang berarti usaha ini akan memberikan keuntungan sebesar Rp 47,417 juta selama 10 tahun menurut nilai sekarang. Nilai Net B/C sebesar 1,74 yang berarti setiap satu rupiah pengeluaran akan memberikan keuntungan sebesar Rp.1,74. Nilai IRR sebesar 35,35 persen lebih besar dari tingkat suku bunga yang berlaku (17 persen), menunjukkan bahwa tingkat kemampuan maksimal yang dapat 
dibayarkan oleh proyek akibat penggunaan sumber-sumber faktor produksi adalah sebesar 35,35 persen.

Berdasarkan kriteria kelayakan pada Tabel 7, dimana NPV bernilai positif, Net $\mathrm{B} / \mathrm{C}$ lebih besar dari satu dan IRR lebih besar dari tingkat suku bunga yang berlaku maka secara kelayakan investasi usaha ini layak untuk diusahakan. Hasil analisis DPB, pada usaha ini dapat diketahui bahwa usaha ini dapat mengembalikan biaya investasi dalam waktu empat tahun lima bulan dua puluh enam hari. Hasil tersebut satu tahun lima bulan 18 hari lebih lama dari pengembalian investasi tanpa mempertimbangakan faktor diskonto $(\mathrm{PP}=$ payback period $)$.

\subsubsection{Analisis Pulang Pokok}

Keadaan pulang pokok (break even point) yaitu keadaan produksi atau penjualan usaha ini dimana jumlah manfaat (penerimaan penjualan) sama besarnya dengan jumlah pengeluaran (biaya). Dengan kata lain usaha ini tidak mendapatkan laba tapi juga tidak menderita rugi. Pulang pokok usaha ini ditinjau dari dua sisi, yaitu berdasarkan harga jual dan voluine produksi yang harus dicapai. Hasil perhitungan analisis pulang pokok industri kecil minuman segar lidah buaya dapat dilihat pada Tabel 8. Berdasarkan hasil analisis pulang pokok pada Tabel 8, dapat diketahui bahwa usaha ini akan mengalami pulang pokok pada saat volume produksi mencapai 296.116 bungkus/sachet atau penerimaan sebesar total biaya produksinya ( $\operatorname{Rp} 310.921 .600)$. Marjin kontribusi dari usaha sebagai berikut :

Tabel 8. Analisis Pulang Pokok Usaha Pengolahan Lidah Buaya (Aloe Vera) Menjadi Granul Effervescent Sebagai Minuman Kesehatan

\begin{tabular}{llc}
\hline No & \multicolumn{1}{c}{ Keterangan } & Jumlah \\
\hline 1. & Total Biaya Produksi (Rp)/ Tahun & 310.921 .600 \\
\hline 2. & Tota1 Produksi (cup)/Tahun & 362.880 \\
\hline 3. & BEP Harga Jual (Rp)/ bungkus & 857 \\
\hline 4. & Harga Jual Produk(Rp)/bungkus & 1.050 \\
\hline 5. & Marjin Kontribusi (\%)/ bungkus & 18,38 \\
\hline 6. & BEP Volume Produksi (bungkus)/Tahun & 296.116 \\
\hline
\end{tabular}

\subsubsection{Analisis Efisiensi Usaha}

Metode ROI (return on invesment) digunakan sebagai alat analisis untuk mengetahui keuntungan usaha sehubungan dengan penggunaan modal investasi. Besamya ROI ditentukan oleh manfaat bersih sesudah pajak yang dicapai dan modal investasi yang digunakan. Hasil perhitungan analisis efisiensi usaha industri kecil minuman segar lidah buaya dapat dilihat pada Tabel 9.

Tabel 9. Analisis Efisiensi Usaha Pengolahan Lidah Buaya (Aloe Vera) Menjadi Granul Effervescent sebagai Minuman Kesehatan

\begin{tabular}{lll}
\hline No & Uraian & Tahun \\
\hline
\end{tabular}




\begin{tabular}{rlrcc}
\hline & & $\mathbf{1}$ & $\mathbf{2 , 4 , 6 ~ \& ~ 8}$ & $\mathbf{3 , 5 , 7 , 9 \& ~ 1 0}$ \\
\hline 1. & Manfaat Bersih (Rp) & 5.608 .640 & 21.320 .125 & 27.200 .000 \\
\hline 2. & Investasi (Rp) & 64.164 .300 & 64.164 .300 & 64.164 .300 \\
\hline 3. & Reinvestasi (Rp) & - & $6,917.500$ & - \\
\hline
\end{tabular}

\section{SIMPULAN}

Berdasarkan uji waktu larut granul effervescent ekstrak lidah buaya tidak memenuhi syarat. Berdasarkan uji kelarutan, uji kadar air, uji waktu alir, granul effervescent ekstrak lidah buaya memenuhi syarat. Hasil dari analisis Net Present Value (NPV), Net Benefit Cost Ratio (Net B/C), Internal Rate of Return (IRR), Payback Period (PP), dan Discounted Payback (DPB) dinyatakan layak. Penelitian ini perlu dikembangkan sebagai sebuah usaha berbasis UMKM (usaha kecil menengah) dengan memanfaatkan sumber daya lokal yaitu lidah buaya dengan menerapkan teknologi tepat guna berdasarkan analisis ekonomi yang menguntungkan dan berkelanjutan dan penelitian ini perlu penelitian lanjutan berkaitan dengan proses produksi maupun studi kelayakan akan pendirian usaha pengolahan lidah buaya secara mendalam dan komprehensif.

\section{DAFTAR PUSTAKA}

Ansel, H. C. (1989). Pengantar Bentuk Sediaan Farmasi. (I. Farida, Ed.) (IV). Jakarta: Universitas Indonesia Press.

Depkes, R. (1995). Farmakope Indonesia (4th ed.). Jakarta: Depkes RI.

Disperindagko \& UMKM. (2016). Perkembangan industri kota Pontianak. Kota Pontianak: Disperindagko dan UMKM.

Furwanti. (2002). Kasiat dan Manfaat Lidah Buaya. Jakarta: Agromedia.

Hindun, P. M., S. dan B. yudha. (2004). Membuat Tanaman Obat. Surabaya: Tekno Pangan.

Husnan, S., \& Suwarsono. (1991). Studi Kelayakan Proyek, Konsep Teknik dan Penyusunan Laporan (Kedua). Yogyakarta: AMP YKPN.

Lachman, L., Lieberman, H.A., Kaning, J. . (1994). Teori dan Praktek Sediaan Farmasi Industri. (S. Suyanti, Ed.) (Jilid II). Jakarta: UI Press.

Lieberman, R. \& B. (1989). Pharmaceutical Dosage Form : Disperse System. Journal of Pharmaceutical Sciences, 2, 495-498.

Monrle, R. (1989). Effervescent Tablet in Pharmaceutical Dosage Form Table, (Marcel Dekker Inc. New York).

Musyafak, akhmad. (2003). Agribisnis Lidah Buaya di Kalimantan Barat Berprospek 
tapi Belum Tergarap. Tabloid Sinar Sari.

Parikh, D. M. (1997). Handbook of Pharmaceutical Granulation Technology. New York: Marcel Dekker, Inc.

Pulungan. (2004). Membuat effervescent Tanaman Obat. Surabaya: Trubus Agrisarana.

Riyanto, B. (2001). Dasar-dasar Pembelanjaan. Yogyakarta: BPFE.

Sutrisno. (2009). Manajemen Keuangan Teori, Konsep dan Aplikasi (Edisi Pert). Yogyakarta: Ekonisia.

Voigt, R. (1995). Buku Pelajaran Teknologi Farmasi. (Soendani N. S, Ed.). Yogyakarta: UGM Press.

Wahyono, \& Kusnandar. (2002). Lidah Buaya. Retrieved September 8, 2012, from http://id.wikipedia.org/wiki/Lidah_Buaya

Wijayanti, M., Saptarini, N., \& Herawati, I. E. (2014). Formulation of Effervescent Granule of Aloe Dry Juice as Food Supplement. Indonesian Journal of Pharmaceutical Science and Technology, 1(1). 